\title{
ANALISIS PENGGUNAAN MEDIA INTERNET PADA MAHASISWA PENDIDIKAN BIOLOGI UNIVERSITAS MATARAM DALAM PEMBELAJARAN DARING DITENGAH PANDEMI COVID-19
}

\section{ANALYSIS OF INTERNET MEDIA USAGE INBIOLOGY EDUCATION STUDENTS OF MATARAM UNIVERSITY IN ONLINE LEARNING AMID THE COVID-19 PANDEMIC}

\author{
Sri Wulan Dari*, Muhlis, dan Kusmiyati \\ Program Studi Pendidikan Biologi, Jurusan PMIPA, FKIP, Universitas Mataram, Mataram, Indonesia \\ *Email: sriwulandari1506@gmail.com
}

Diterima: 9 Maret 2021. Disetujui: 10 Mei 2021. Dipublikasikan: 2 Juni 2021

\begin{abstract}
Abstrak: Pandemi Covid-19 yang mewabah pada tahun 2019 mengakibatkan pembelajaran tatap muka ditiadakan dan diganti dengan pembelajaran daring/online untuk menekan laju penyebaran virus Covid-19. Penelitian ini bertujuan untuk mengetahui penggunaan media internet pada mahasiswa pendidikan biologi Universitas Mataram selama pembelajaran daring ditengah pandemi Covid-19. Penelitian ini menggunakan pendekatan kuantitatif dengan metode deskriptif. Penelitian ini menggunakan sampel jenuh. Penelitian ini melibatkan 96 mahasiswa semester 4 pada program studi pendidikan biologi. Teknik pengumpulan data pada penelitian ini menggunakan angket skala likert. Angket dibuat dalam google form serta bantuan aplikasi WhatsApp. Teknik analisis data yang digunakan pada penelitian ini adalah menghitung persentase data dari setiap indikator, kemudian menginterpretasi skor persentasi data dan menganalisis setiap indikatornya. Hasil penelitian menunjukkan bahwa penggunaan media internet pada mahasiswa pendidikan biologi semester 4 Universitas Mataram pada variabel pemanfaatan media internet berada pada kategori sangat tinggi dengan persentase $28 \%$, tinggi dengan persentase $67 \%$ dan cukup dengan persentase $2 \%$. Sedangkan pada variabel jenis aplikasi yang digunakan selama pembelajaran daring, didapatkan hasil bahwa aplikasi yang digunakan yakni WhatsAppe sebesar 29\%, Zoomsebesar 21\%, Google Meetsebesar 21\%, Spada Unramsebesar 28\%, dan lainnya sebesar $1 \%$ yang terdiri dari aplikasi Timelink, Line, YouTube, dan pembelajaran tatap muka.
\end{abstract}

Kata Kunci: Pembelajaran daring, Pemanfaatan Media Internet, Pandemi Covid-19

\begin{abstract}
The Covid-19 pandemic that broke out in 2019 resulted in face-to-face learning being eliminated ande replaced with online learning to reduce the rate of Covid-19 virus spread. This study aims to know the use of internet media in biology education students Mataram University during online learning amid the Covid-19 pandemic. This research uses a quantitative approach with descriptive methods. This study uses a saturated sample. This study ivolved 96 student of biology education program in $4^{\text {th }}$ semester. Data collection techniques in this study used a Likert scale questionnaire. The questionnaire was created in Google Form and the WhatsApp application assistance. Data analysis technique used in this tudy is calculate the percentage of data from each indicator, then interpret the data percentage score of each indicator. The result showed that the use of internet media in $4^{\text {th }}$ semester biology education student of Mataram University on variable of internet media utilization the use of internet media is in the very high by percentage $28 \%$, high $67 \%$ and sufficient category $2 \%$. Whereas in the type of application variable used during online learning, the result show that the applications used are WhatsApp 29\%, Zoom 21\%, Google Meet 21\%, Spada Unram 28\%, and others 1\% which consist of Timelink, Line, YouTube application, and face-to-face learning.
\end{abstract}

Keywords: Online Learning, Use of Internet Media, The Covid-19 Pandemic

\section{PENDAHULUAN}

Pembelajaran dengan metode konvensional tidak lagi menjadi solusi pada pembelajaran abad 21 dikarenakan tantangan pada abad 21 ini memerlukan penggunaan teknologi dalam setiap proses pembelajaran. Perkembangan zaman memerlukan pemodifikasian model pembelajaran untuk beradaptasi dengan era digitalisasi abad 21 yaitu pemanfaatan teknologi [1]. Penyesuaian pendidikan terutama dalam proses pembelajaran terhadap perkembangan teknologi harus terus dilakukan untuk meningkatkan mutu pendidikan. Saat ini internet memberikan jangkauan 
yang luas, cepat, efektif, dan efisien terhadap pengemasan dan penyebarluasan informasi ke berbagai penjuru dunia adalah sistem teknologi dan komunikasi. Teknologi informasi dan komunikasi ini memang sangat dibutuhkan dalam dunia pendidikan [2].

Pembelajaran online merupakan salah satu bentuk alternatif dari pembelajaran yang menggunakan fasilitas internet dengan aksesibilitas, konektivitas, fleksibilitas, dan kemampuan untuk memunculkan berbagai jenis interaksi pembelajaran [3]. Pembelajaran online pada pelaksanaanya membutuhkan dukungan dari beberapa macam perangkat mobile seperti smart phone, tablet, laptop, dan lain-lain yang dapat digunakan untuk mengakses informasi dimana saja dan kapan saja[4]. Pembelajaran daring dapat dijadikan solusi pembelajaran jarak jauh ketika terjadi bencana alam. Seperti yang terjadi ketika pemerintah menetapkan kebijakan social distancing. Penerapan social distancing dikarenakan virus seperti COVID-19 ini menyebar secara contagious yang merupakan sebuah istilah yang mengacu pada infeksi yang penyebarannya secara cepat [5]. Penggunaan teknologi mobile memiliki kontribusi yang sangat besar di dunia pendidikan termasuk di dalamnya adalah pencapaian tujuan pembelajaran jarak jauh [6]. Pemerintah menerapkan social distancing dalam rangka membatasi interaksi manusia dan menghindarkan masyarakat dari kerumunan agar terhindar dari penyebaran virus COVID-19. Kebijakan ini menjadikan kegiatan belajar mengajar dalam konteks tatap muka diberhentikan sementara. Pemerintah mengganti pembelajaran dengan sistem pembelajaran daring melalui aplikasi pembelajaran daring yang sudah ada[7].

Pembelajaran daring, pembelajaran online atau pembelajaran jarak jauh sendiri merupakan suatu metode pembelajaran yang bertujuan untuk memenuhi standar pendidikan dengan pemanfaatan teknologi informasi dengan menggunakan perangkat komputer atau gadget yang saling terhubung antara siswa dengan guru atau antara mahasiswa dengan dosen sehingga melalui pemanfaatan teknologi tersebut proses belajar mengajar bisa tetap berjalan dengan baik meskipun tengah berada dalam masa pandemi COVID- 19, hal ini dimungkinkan dapat terlaksana dengan baik mengingat masyarakat Indonesia saat ini mayoritasnya sudah menggunakan internet. Menurut penelitian WE ARE SOSIAL, "Digital Reports 2020" yang dirilis pada akhir Januari 2020 menyatakan bahwa hampir 64 pesen penduduk Indonesia sudah terkoneksi dengan jaringan internet. Jumlah pengguna internet di Indonesia sudah mencapai 175,4 juta orang dari jumlah total penduduk sebanyak 272,1 juta jiwa dan jika dibandingkan dengan tahun 2019, jumlah pengguna internet di Indonesia meningkat sekitar 17 persen atau sebanyak 25 juta pengguna[8].

Saat ini terdapat beberapa teknologi informasi yang dapat dimanfaatkan sebagai media pembelajaran. Media memiliki arti tengah, perantara atau pengantar [9]. Media adalah alat bantu yang berupa apa saja dan dapat dijadikan sebagai penyalur pesan guna mencapai tujuan pembelajaran. Media sebagai bentuk dari semua perantara yang digunakan oleh manusia untuk menyampaikan ide, gagasan atau pendapat sehingga dapat tersampaikan kepada penerima yang dituju [10]. Media adalah segala alat fisik yang dapat menyajikan pesan serta merangsang peserta didik untuk belajar sehingga tercapainya tujuan pembelajaran [11]. Pemanfaatan media dimasa pandemi COVID-19 ini diantaranya dengan menggunakan e-learning. $E$ learning merupakan model pembelajaran yang pemanfaatannya menggunakan fasilitas teknologi informasi dan komunikasi jarak jauh yang mendukung proses pembelajaran non tatap muka. Selain e-learning ada beberapa pemanfaatan teknologi lainnya yang digunakan untuk meningkatkan proses belajar mengajar melalui pembelajaran jarak jauh diantaranya dengan penggunaan media komunikasi seperti WhatsApp, Google Class, YouTube, maupun aplikasi zoom yang bisa mempertemukan dosen dan mahasiswa secara virtual sehingga proses belajar mengajar bisa tersampaikan dengan baik [8].

Universitas Mataram yang juga merupakan salah satu institusi pendidikan tinggi turut merespon kebijakan Pemerintah serta menjalankan arahan Pemerintah dan Menteri Pendidikan Kebudayaan dalam melaksanakan pembelajaran jarak jauh dalam rangka menekan laju penyebaran COVID- 19. Hal ini sesuai dengan surat edaran Rektor Nomor: 3327/UN18/TU/2020, perihal perkuliahan e-learning dan bantuan yang akan diberikan pihak universitas kepada mahasiswa berupa kuota internet. Sehingga berdasarkan uraian diatas, pendidikan biologi yang merupakan salah satu program studi di fakultas keguruan dan ilmu pendidikan menerapkan peraturan yang ditetapkan pemerintah maupun pihak universitas untuk melaksanakan perkuliahan melalui daring/ online dengan memanfaatkan media intenet.

Database Universitas Mataram, jumlah mahasiswa Pendidikan Biologi yang aktif sebanyak 384 orang mahasiswa dan terdiri dari beberapa semester yang berbeda. Mahasiswa Pendidikan Biologi semester 4 tahun 2020 berjumlah 98 orang yang sudah mengikuti perkuliahan daring selama pandemi Covid-19 dengan 7 mata kuliah wajib Pendidikan Biologi yakni Zoologi Vertebrata, Botani Tumbuhan Rendah, Morfologi Perkembangan Tumbuhan, Genetika, Statistika Dasar, Strategi Pembelajaran Biologi, dan Telaah Kurikulum Biologi. Penelitian ini bertujuan untuk menganalisa penggunaan media internet yang terdiri dari pemanfaatan media internet dan jenis aplikasi yang digunakan pada masing-masing mata kuliah wajib pada semester 4 Pendidikan Biologi Universitas Mataram 
tahun 2020 .

\section{METODE PENELITIAN}

Penelitian ini merupakan penelitian kuantitatif dengan metode deskriptif. Penelitian dilaksanakan melalui angket yang diisi pada google form dan dilaksanakan pada tanggal 14 Desember 2020 - 3 Januari 2021. Populasi dalam penelitian ini adalah mahasiswa program studi Pendidikan Biologi Universitas Mataram semester 4 tahun 2020 yang aktif

Analisis data yang digunakan pada penelitian ini adalah dengan menggunakan metode deskriptif kuantitatif dengan menghitung persentase dari skor yang diperoleh, adapun rumus dalam menghitung persentasenya adalah sebagai berikut [13].

Keterangan:

$$
D p=\frac{n}{N} \times 100 \%
$$

$$
\begin{array}{ll}
D p & =\text { Skor yang diharapkan } \\
\mathrm{N} & =\text { Jumlah skor maksimal } \\
n & =\text { Jumlah skor yang diperoleh }
\end{array}
$$

Hasil persentase yang diperoleh dilakukan interpretasi skor berdasarkan tabel interval berikut ini [14].

Tabel 1. Skala Likert

\begin{tabular}{ll}
\hline Kriteria Penilaian & Skala Penilaian \\
\hline Sangat Setuju & 5 \\
Setuju & 4 \\
Cukup/Netral & 3 \\
Tidak Setuju & 2 \\
Sangat Tidak & 1 \\
Setuju & \\
\hline
\end{tabular}

Tabel 2. Kriteria Interpretasi Skor

\begin{tabular}{lc}
\hline Persentase & Keterangan \\
\hline $0 \%-20 \%$ & Sangat Rendah \\
$21 \%-40 \%$ & Rendah \\
$41 \%-60 \%$ & Cukup \\
$61 \%-80 \%$ & Tinggi \\
$81 \%-100 \%$ & Sangat tinggi
\end{tabular}

Hasil perhitungan diatas akan menjadi dasar dalam menganalisis dan menyimpulkan bagaimana penggunaan media internet mahasiswa semester 4 program studi pendidikan biologi di Universitas Mataram pada pembelajaran daring selama pandemi Covid-19. Untuk angket terbuka hanya dilakukan pengitungan persentase media internet atau aplikasi yang digunakan dalam mata kuliah wajib semester 4 pendidikan biologi dalam perkuliahan daring ditengah pandemi Covid-19.

\section{HASIL DAN PEMBAHASAN}

menggunakan media internet untuk perkuliahan daring selama pandemi Covid-19 dengan total mahasiswa 96 orang. Teknik pengambilan sampel menggunakan teknik sampel jenuh.Pengumpulan data dilakukan dengan pemberian kuesioner melalui google form. Angket yang digunakan dalam penelitian ini dalam bentuk skala likert. Skala likert digunakan sebagai alat untuk mengukur sikap, pendapat, dan persepsi individu atau sekelompok orang terhadap suatu fenomena sosial [12]. Adapun tabel skala likert disajikan tabel 1.

\section{Pemanfaatan Media Internet}

Tingkat pemanfaatan media internet selama pembelajaran daring di tengah pandemi Covid-19 pada mahasiwa Pendidikan Biologi semester 4 angkatan 2018 Universitas Mataram terangkum pada Tabel 3.

\section{Jenis Aplikasi yang digunakan}

Data hasil penelitian tentang penggunaan aplikasi selama pembelajaran daring pada mahasiswa Pendidikan Biologi semester 4 angkatan 2018 Universitas Mataram diambil menggunakan kuesioner (angket) online yang diisi melalui Google Form, kemudian disajikan dalam bentuk deskriptif persentase. Data hasil penelitian tentang aplikasi yang digunakan selama pembelajaran daring per mata kuliah tersaji pada tabel 4 .

Pembahasan dalam penelitian ini didasarkan pada hasil penelitian yang telah dipaparkan sebelumnya. Analisis penggunaan media internet pada mahasiswa pendidikan Biologi semester 4 angkatan 2018 Universitas Mataram terdiri dari dua indikator. Indikator pertama yakni pemanfaatan media internet dan indikator kedua yakni jenis aplikasi yang digunakan.

Indikator pemanfaataan media internet terdiri dari beberapa sub indikator, yakni sub indikator intensitas penggunaan media internet, kemanfaatan media internet,dan efektifitas media internet dalam pembelajaran daring selama pandemi Covid-19. Berdasarkan data pada tabel 3.dapat diketahui bahwa tingkat pemanfaatan media internet selama pembelajaran daring di tengah pandemi Covid-19 pada mahasiwa Pendidikan Biologi semester 4 angkatan 2018 Universitas Mataram sebesar $28 \%$ atau sebanyak 27 orang dari 96 responden dengan kriteria sangat tinggi, $70 \%$ atau 67 orang dari 96 respondenpada kriteria tinggi, 2\% atau sebanyak 2 orang dari 96 responden berada pada kriteria cukup,dan $0 \%$ atau tidak ada dari 96 responden yang berada pada kategori rendah maupun sangat rendah dalam

tingkat penggunaan media internet. Dapat disimpulkan bahwa penggunaan media internet pada mahasiswa pendidikan biologi dengan kategori tinggi memiliki persentase terbesar.

Pemberlakuan social distancing untuk mencegahan Covid-19 ini mendorong penggunaan media informasi dan komunikasi untuk bekerja dan belajar secara online. Bekerja ataupun belajar harus 
tetap berlangsung di dalam rumah. Bekerja dan belajar dari rumah dapat dilaksanakan dengan menggunakan sejumlah variasi platform yang telah ada agar kegiatan tetap terlaksana dengan baik [15]. Pembelajaran daring yang dilaksanakan secara online dilakukan sebagai strategi pemelajaran yang menyenangkan bagi pebelajar (mahasiswa) karena dapat menyimak pembelajaran melalui smartphone, laptop, maupun komputer dan bukan hanya sekedar menyimak buku [16]. Berdasarkan data hasil penelitian, penggunaan aplikasi internet dalam pembelajaran daring di tengah pandemi Covid-19 pada mahasiswa Pendidikan Biologi semester 4 Universitas Mataram dapat diketahui bahwa penggunaan aplikasi internet pada masing-masing mata kuliah wajib, pada mata kuliah Zoologi Vertebrata, aplikasi yang digunakan yaitu aplikasi WhatsApp, Zoom, Google Meet, Spada Unram dan Timelink. Persentase penggunaan aplikasi WhatsApp sebesar 25\%, aplikasi Zoom sebesar 24\%, aplikasi Google Meet sebesar 25\%, aplikasi SpadaUnram 25\%, dan Timelink sebesar $1 \%$.

Aplikasi yang digunakan pada mata kuliah Botani Tumbuhan Rendah yaitu aplikai WhatsApp, Zoom, Google Meet, dan Spada Unram. Presentse penggunaan aplikasi WhatsApp sebesar 26\%, aplikasi Zoom sebesar 25\%, aplikasi Google Meet 25\%, dan aplikasi Spada Unram sebesar 24\%. Data aplikasi yang digunakan pada mata kuliah Morfologi Perkembangan Tumbuhan, aplikasi yang digunakan hanya WhatsApp dan Spada Unram. Persentase penggunaan aplikasi WhatsApp sebesar 51\% dan penggunaan aplikasi Spada Unram sebesar 49\%. Data aplikasi yang digunakan pada mata kuliah Genetika, aplikasi yang digunakan yaitu WhatsApp, Zoom, Google Meet, Spada Unram, dan Line. Persentase penggunaan aplikasi WhatsApp sebesar 26\%, aplikasi Zoom sebesar 24\%, aplikasi Google Meet sebesar 25\%, aplikasi Spada Unram sebesar 24\%, dan aplikasi Line sebesar $0 \%$ karena hanya satu orang dari 96 responden yang menjawab Line. Aplikasi yang digunakan pada mata kuliah Statistika Dasar yaitu WhatsApp, Zoom, Google Meet, Spada Unram dan YouTube. Penggunaan aplikasi WhatsApp sebesar 24\%, aplikasi Zoom sebesar 23\%, aplikasi Google Meet sebesar 23\%, aplikasi Spada Unram sebesar 23\%, dan aplikasi YouTube sebesar 7\%. Aplikasi yang digunakan pada mata kuliah Strategi Pembelajaran Biologi yaitu WhatsApp, Zoom, Google Meet, Spada Unram dan kuliah tatap muka. Presentasi penggunaan aplikasi WhatsApp sebesar 25\%, aplikasi Zoom sebesar 25\%, aplikasi Google Meet sebesar 25\%, aplikasi Spada Unram sebesar 24\%, dan kuliah tatap muka sebesar $1 \%$. Aplikasi yang digunakan pada mata kuliah Telaah Kurikulum Biologi yaitu aplikasi WhatsApp, Zoom, Google Meet, dan Spada Unram. Persentase penggunaan aplikasi WhatsApp sebesar 26\%, aplikasi Zoom sebesar 25\%, aplikasi Google Meet sebesar 25\%, dan aplikasi Spada Unram sebesar $25 \%$.
Data penggunaan aplikasi selama perkuliahan daring selama pandemi Covid-19 pada masing-masing mata kuliah wajib pada semester 4 Pendidikan Biologi Universitas Mataram yang dikumpulkan kemudian di hitung rata-rata penggunaan dari masing-masing aplikasi sehingga didapatkan kesimpulan aplikasi yang paling banyak digunakan. Aplikasi yang paling sering digunakan/ disebut adalah aplikasi WhatsApp sebesar 29\%, kemudian aplikasi Spada Unram sebesar 28\%, aplikasi Zoom dan Google Meet sebesar 21\%, dan lainnya yang terdiri dari Timelink, Line, YouTube, dan kuliah tatap muka sebesar $1 \%$. Penggunaan aplikasiaplikasi untuk pembelajaran daring ditengah pandemi Covid-19 ini memiliki persentase yang beragam dikarenakan masing-masing aplikasi yang digunakan memiliki kekurangan dan kelebihan masing-masing. Aplikasi WhatsApp memiliki kelebihan yaitu teknologi server dan jaringan yang berkembang saat ini berkembang sangat pesat, salah satunya adalah aplikasi WhatsApp. Aplikasi WhatsApp dapat digunakan sebagai e-learning, dan aplikasi WhatsApp mudah untuk di operasikan dan gratis. Kekurangan dari aplikasi WhatsApp yaitu tidak semua aplikasi dapat diintegrasikan ke dalam sistem [17]. Sedangkan kelebihan dari aplikasi Zoom yaitu aplikasi Zoom dapat digunakan untuk video conference yang memiliki beberapa fitur untuk melakukan seminar secara online terdapat pembicara aktif dan 100 peserta, dan memiliki fitur file sharing yang dapat mengirimkan file berupa foto, video, dan dokumen, namun aplikasi Zoom juga memiliki kekurangan yatu kebutuhan setiap sistem operasi berbeda yang mengharuskan instalasi di setiap perangkat berbeda [18]. Aplikasi Google Meet memiliki kelebihan yakni aplikasi Google Meet terintegrasi dengan $G$ Suite, yang memungkinkan pengguna untuk dapat bergabung langsung dari kalender atau undangan yang dikirim via email. Selain itu, aplikasi Google Meet juga tesedia gratis, memiliki banyak fitur, dan terjamin keamanannya, serta kelebihan lainnya. Google Meet juga memiliki kekurangan diantaranya tidak ada fitur hemat data, membutuhkan jaringan internet yang stabil, dan belum semua fasilitas dari Google Meet gratis [19]. Aplikasi Spada Unram, sistem ini dapat melakukan tugasnya dengan baik dan dapat menampilkan hasil yang sesuai dengan performa masing-masing mata kuliah dan dosen, namun sistem ini masih memiliki kekurangan yaitu belum memiliki fitur yang banyak [20]. Perbedaan persentase penggunaan aplikasi pada masing-masing mata kuliah terjadi karena dosen yang mengampu mata kuliah tertentu menggunakan aplikasi tertentu yang mengakibatkan mahasiswaharus menggunakan aplikasi yang ditentukan oleh dosen yang mengampu mata kuliah. Persentase penggunaan aplikasi yang berbedabeda dimungkinkan karena penggunaan aplikasi yang paling mudah digunakan sehingga aplikasi tersebut dipilih oleh dosen pengampu mata kuliah sehingga 
sering digunakan.

Tabel 3. Data Tingkat Pemanfaatan Media Internet

\begin{tabular}{lcc}
\hline \multicolumn{1}{c}{ Kriteria } & Jumlah Respon Mahasiswa & Persentase \\
\hline Sangat Tinggi & 27 & $28 \%$ \\
Tinggi & 67 & $70 \%$ \\
Cukup & 2 & $2 \%$ \\
Rendah & 0 & $0 \%$ \\
Sangat Rendah & 0 & $0 \%$ \\
Jumlah total responden & 96 & $100 \%$ \\
\hline
\end{tabular}

Tabel 4. Data Penggunaan Aplikasi Internet

\begin{tabular}{lcccccccc}
\hline \multicolumn{1}{c}{ Aplikasi } & \multicolumn{2}{c}{ Persentase Penggunaan Aplikasi pada Mata Kuliah Wajib } & Persentase \\
& Zover & BTR & Mortum & Semester 4 & Genetika & SD & SPB & Telkur \\
Bio & $\begin{array}{c}\text { Penggunaan } \\
\text { Aplikasi }\end{array}$ \\
\hline WhatsApp & $25 \%$ & $26 \%$ & $51 \%$ & $26 \%$ & $24 \%$ & $25 \%$ & $26 \%$ & $29 \%$ \\
Zoom & $24 \%$ & $25 \%$ & $0 \%$ & $24 \%$ & $23 \%$ & $25 \%$ & $25 \%$ & $21 \%$ \\
Google Meet & $25 \%$ & $25 \%$ & $0 \%$ & $25 \%$ & $23 \%$ & $25 \%$ & $25 \%$ & $21 \%$ \\
Spada Unram & $25 \%$ & $24 \%$ & $49 \%$ & $24 \%$ & $23 \%$ & $24 \%$ & $24 \%$ & $28 \%$ \\
Lainnya & $1 \%$ & $0 \%$ & $0 \%$ & $0 \%$ & $7 \%$ & $1 \%$ & $0 \%$ & $1 \%$ \\
\hline
\end{tabular}

Keterangan:

Zover

BTR

Mortum

$\mathrm{SD}$

SPB

Telkur Bio
: Zoologi Vertebrata

: Botani Tumbuhan Rendah

: Morfologi Perkembangan Tumbuhan

: Statistika Dasar

: Strategi Pembelajaran Biologi

: Telaah Kurikulum Biologi

\section{KESIMPULAN}

Berdasarkan hasil penelitian dan analisis temuan-temuan selama penelitian maka diperoleh kesimpulan bahwa pemanfaatan media internet pada mahasiswa Pendidikan Biologi Universitas Mataram semester 4 angkatan 2018 dengan persentase terbesar pada kriteria tinggi yakni sebesar $70 \%$, sehingga dapat disimpulkan bahwa pemanfaatan media internet pada mahasiswa Pendidikan Biologi semester 4 angkatan 2018 Universitas Mataram tinggi dalam pembelajaran daring ditengah pandemi Covid-19. Jenis aplikasi yang digunakan selama pembelajaran daring ditengah pandemi Covid-19 oleh mahasiswa Pendidikan Biologi semester 4 angkatan 2018 Universitas Mataram yaitu aplikasi WhatsApp, Zoom, Google Meet, Spada Unram, serta pilihan lainnya yaitu aplikasi TimeLink, aplikasi Line, aplikasi YouTube, dan pembelajaran tatap muka.

\section{DAFTAR PUSTAKA}

[1] Ihsan, M.S., Ramdani, A., dan Hadisaputra, S. (2019). Pengembangan E-Learning pada Pembelajaran Kimia untuk Meningkatkan Kemampuan Berpikir Kritis Peserta Didik. Jurnal Pijar MIPA, 14 (2), 84-87.

[2] Rusman. (2013). Metode-Metode Pembelajaran:
Mengembangkan Profesionalisme Guru. Jakarta: PT Raja Grafindo Persada.

[3] Firman, dan Rahma, S.R. (2020). Pembelajaran Online di Tengah Pandemi Covid-19. Indonesian Journal of Educational Science (IJES), 2 (2), 81-89.

[4] Gikas, J., dan Grant, M. (2013). Mobile Computing Devices in Higher Education: Student Perspectives on Learning with Cellphones, Smartphones \& Social Media. Internet and Higher Education.

[5] Mona, N. (2020). Konsep Isolasi dalam Jaringan Sosial Untuk Meminimalisir Efek Contagious (Kasus Penyebaran Virus Corona di Indonesia). Jurnal Sosial Humaniora Terapan, 2 (2), 117-125.

[6] Korucu, A.T., \& Alkan, A. (2011). Differences Between M-learning (Mobile Learning) and Elearning Basic Terminology and Usage of Mlearning In Education. Procedia - Social and Behavioral Sciences, 4 (29), 1925-1930.

[7] Syarifudin, A. (2020). Implementasi Pembelajaran Daring Untuk Meningkatkan Mutu Pendidikan Sebagai Dampak Diterapkannya Social Distancing. Jurnal Pendidikan Bahasa Indonesia dan Sastra Indonesia, 5 (1): 31-34.

[8] Pakphan, R.,\& Fitriani, Y. (2020). Analisa Pemanfaatan Teknologi Informasi dalam 
Pembelajaran Jarak Jauh di Tengah Pandemi Virus Corona Covid-19. Journal of Information System, Applied, Management, Accounting and Research, 4 (2), 30-36.

[9] Arsyad, A. (2013). Media Pembelajaran. Jakarta: PT Raja Grafindo Persada.

[10]Zamarah, S.B., dan Zain. A. (2013). Strategi Belajar Mengajar. Jakarta: Rineka Cipta.

[11] Yani, E. (2018). Skripsi: Analisis Penggunaan Media Internet Terhadap Minat Belajar Biologi Peserta Didik Kelas XII SMA Negeri Se-Kota Bandar Lampung. Lampung: Universitas Islam Negeri Raden Intan.

[12] Sugiyono. (2016). Metode Penelitian Kuantitatif, Kualitatif dan $R \& D$. Bandung: Alfabeta.

[13]Ali, M. (2013). Penelitian Kependidikan dan Strategi. Bandung: Angkasa.

[14] Fitriyani, Y., FauziI., dan Sari, M.Z. (2020). Motivasi Belajar Mahasiswa pada Pembelajaran Daring Selama Pandemik Covid-19. Jurnal Kependidikan: Jurnal Hasil Penelitian dan Kajian Kepustakaan di Bidang Pendidikan, Pengajaran dan Pembelajaran, 6 (2), 165-175.

[15] Gunawan, Suranti, N.Y., dan Fathoroni. (2020. Variation of Models and Learning Platforms for Prospective Teachers During the Covid-19
Pandemic Period. Indonesian Journal of Teacher Education, 1 (2), 61-70.

[16] Argaheni, N.B. (2020). Sistematik Review: Dampak Perkuliahan Daring Saat Pandemi Covid-19 Terhadap Mahasiswa Indonesia. PLACENTUM Jurnal Ilmiah Kesehatan dan Aplikasinya, 8 (2), 99108.

[17] Prajana, A. (2017). Pemanfaatan Aplikasi WhatsApp dalam Media Pembelajaran di UIN ArRaniry Banda Aceh. Jurnal Pendidikan Teknologi Informasi, 1 (2), 122-133.

[18] Azzam, F.N, dkk. 2019. Implementasi Video Conference dengan File Sharing Menggunakan WebRTC. Jurnal Pengembangan Teknologi Informasi dan Ilmu Komputer, 3 (10), 10102-10109.

[19] Sawitri, D. (2020). Penggunaan Google Meet untuk Work From Home di Era Pandemi Coronavirus Disease 2019 (Covid-19). Jurnal Pengabdian Masyarakat, 2 (1), 13-21.

[20]Bimantoro, F., Widiartha, I.B.K., Wijaya, I.G.P.S.,dan Husodo, A.Y. (2019). Integrasi Sistem Informasi Kepuasan Belajar Mengajar Program Studi Teknik Informatika dengan Sistem Informasi Akademik Unram Menggunakan Web Service. JTIKA, 1 (1), 86-93. 